Bài báo khoa học

\title{
Hiệu quả, đóng góp của ngành Công an trong công tác ứng phó với biến đổi khí hậu, phòng chống thiên tai và tìm kiếm cứu nạn
}

\section{Nguyễn Văn Khiêm ${ }^{*}$, Huỳnh Thị Lan Hương², Mai Văn Khiêm³ ${ }^{2}$ Đỗ Thị Hương Nguyễn Ngọc Chung ${ }^{5}$}

${ }^{1}$ Văn phòng Bộ Công an; khiemuptbca@gmail.com

${ }^{2}$ Viện Khoa học Khí tượng Thủy văn và Biến đổi khí hậu; huynhlanhuong@gmail.com

3 Trung tâm khí tượng thủy văn quốc gia; maikhiem1977@gmail.com

${ }^{4}$ Viện Khoa học Khí tượng Thủy văn và Biến đổi khí hậu;dohuong@gmail.com

${ }^{5}$ Văn phòng Bộ Công an; chung.upt@gmail.com

*Tác giả liên hệ: khiemuptbca@gmail.com; Tel: +84-913555223

Ban Biên tập nhận bài: 5/7/2021; Ngày phản biện xong: 9/8/2021; Ngày đăng bài: $25 / 10 / 2021$

Tóm tắt: Biến đổi khí hậu $(\mathrm{BĐKH})$ là một trong những thách thức lớn nhất của nhân loại trong thế kỷ 21 , đã, đang và sẽ làm thay đổi toàn diện sâu sắc quá trình phát triển và an ninh toàn cầu. BĐKH sẽ làm gia tăng tần suất và cườn độ thiên tai. Trong nhiều năm qua, Chính phủ Việt Nam đã đạt được những tiến bộ đáng ghi nhận trong công tác phòng tránh và giảm nhẹ rủi ro thiên tai. Ngành Công an là một trong những bộ/ ngành đóng góp quan trọng trong những nỗ lực của Việt Nam trong công tác phòng chống thiên tai, đặc biệt trong công tác ứng phó với $\mathrm{BĐKH.} \mathrm{Để} \mathrm{có} \mathrm{thể} \mathrm{nâng} \mathrm{cao} \mathrm{hiệu} \mathrm{quả} \mathrm{đóng} \mathrm{góp} \mathrm{này} \mathrm{của} \mathrm{ngành} \mathrm{Công} \mathrm{an,} \mathrm{cần} \mathrm{thiết}$ phải đánh giá được hiện trạng công tác ứng phó với $\mathrm{BĐKH,} \mathrm{phòng} \mathrm{chống} \mathrm{thiên} \mathrm{tai} \mathrm{và} \mathrm{tìm}$ kiếm cứu nạn của ngành. Trên cơ sở áp dụng quy trình quản lý rủi ro thiên tai khép kín 4 bước: (1) Phòng ngừa, giảm thiểu; (2) Chuẩn bị sẵn sàng; (3) Úng phó trong và ngay sau thiên tai; (4) Phục hồi và tái thiết, bài báo này trình bày kết quả đánh giá theo 4 nhóm nội dung: (i) Cơ cấu tổ chức; (ii) Xây dựng và lập kế hoạch, (iii) Nguồn lực, và (iv) Trình độ và kỹ năng của lực lượng Công an nhân dân (CAND) tham gia công tác ứng phó với biến đổi khí hậu, phòng chống thiên tai và tìm kiếm cứu nạn.

Từ khóa: Ứng phó với biến đổi khí hậu; Phòng chống thiên tai; Tìm kiếm cứu nạn.

\section{Mở đầu}

Quy trình quản lý thiên tai khép kín (Disaster management cycle) là một công cụ quan trọng và được sử dụng phổ biến ở nhiều quốc gia và vùng lãnh thổ [1]. Nhiều tổ chức, các nhà khoa học sử dụng khái niệm quy trình quản lý thiên tai khép kín là quá trình liên tục, trong đó các chính phủ, doanh nghiệp và xã hội dân sự lập kế hoạch và giảm thiểu các tác động của thiên tai, phản ứng trong và ngay sau khi thiên tai xảy ra và thực hiện các bước để phục hồi sau khi xảy ra thiên tai (điển hình như Trung tâm nghiên cứu phát triển toàn cầu (GDRC) São Carlos Brazil [2]). Quy trình quản lý thiên tai khép kín do [3] đề xuất bao gồm sáu giai đoạn khác nhau: (i) tái thiết, (ii) giảm nhẹ và dự báo, (iii) khả năng sẵn sàng ứng phó, (iv) cảnh báo, (v) cứu trợ và (vi) phục hồi. Quy trình do Chương trình Phát triển Liên hợp quốc (UNDP) và Tổ chức cứu trợ thiên tai của Liên hợp quốc (UNDRO) đề xuất bao gồm năm giai đoạn. Trong khi đó quy trình kép kín với 3 giai đoạn gồm ứng phó trong thiên tai, phục hồi sau 
thiên tai và giai đoạn chuẩn bị và giảm nhẹ trước thiên tai được đề cập đến trong một số tài liệu khác [1-2].

Ngoài ra, có nhiều quy trình quản lý thiên tai khép kín khác bao gồm hai giai đoạn là trước khi xảy ra thiên tai (gồm phòng ngừa, giảm nhẹ và chuẩn bị sẵn sàng ứng phó) và sau khi xảy ra thiên tai (gồm phục hồi và giảm nhẹ) [4]. Tương tự, [5] nhận định quy trình quản lý thiên tai khép kín là một quá trình liên tục của 2 giai đoạn: Giai đoạn trước thiên tai gồm Giảm nhẹ (giảm thiểu rủi ro và phơi lộ trước thiên tai) và Chuẩn bị sẵn sàng (lập kế hoạch, chuẩn bị sẵn sàng ứng phó và ngăn ngừa hiểm họa); Giai đoạn sau thiên tai gồm Ứng phó (giảm tác động của thiên tai thông qua các nỗ lực ứng phó và tìm kiếm cứu nạn) và phục hồi (thông qua dọn dẹp và tái thiết).

Tuy nhiên, quy trình kín quản lý thiên tai bao gồm bốn giai đoạn được xem là phổ biến hơn cả [6]. Quy trình này được ghi nhận trong nghiên cứu của Alexander vào năm 2002 [2]. Quy trình quản lý hiểm họa của Ngân hàng phát triển Châu Á (ADB) bao gồm 4 giai đoạn là sự tổng hòa và kết hợp của các hoạt động liên tiếp. ADB nhấn mạnh quan điểm, để có hiệu quả, quản lý thiên tai cần được thực hiện như một hoạt động toàn diện và liên tục, không phải là một phản ứng định kỳ đối với các tình huống thiên tai riêng lẻ [7]. Cụ thể, quy trình quản lý thiên tai sử dụng cho các chương trình phát triển và các nước thành viên của $\mathrm{ADB}$ được khuyến cáo áp dụng như Hình 1 . Tương tự với quy trình khép kín như $\mathrm{ADB}$ và nhiều tổ chức quốc tế, quốc gia cũng như nhiều nghiên cứu đã đề cập đến ở trên, chính quyền bang Queensland ở Úc cũng tập trung vào quy trình khép kín tương tự trong quản lý các rủi ro và thực hiện các hành động phòng chống thiên tai (PCTT) [8].

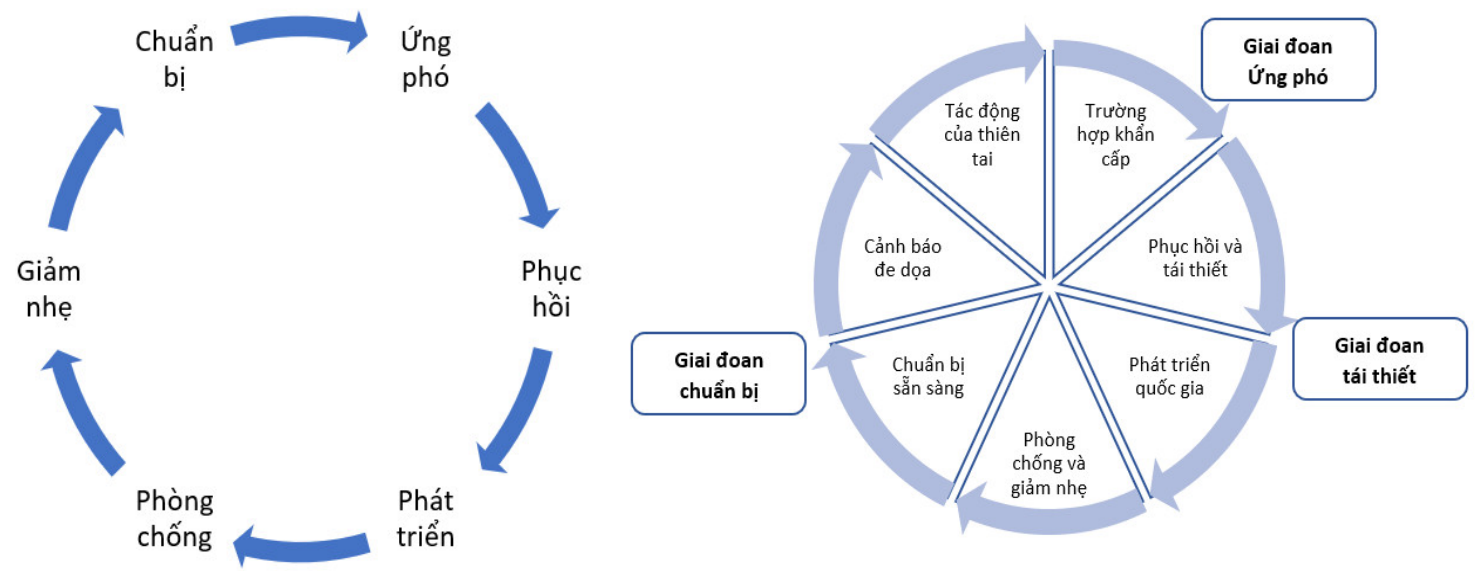

Hình 1. Quy trình quản lý thiên tai cơ bản của ADB [7].

Cơ quan Quản lý Khẩn cấp Liên bang Hoa Kỳ (FEMA) quản lý, phản hồi và thực hiện các giải pháp phục hồi, giảm thiểu các tác động của thiên tai/các trường hợp khẩn cấp theo 04 giai đoạn: Giai đoạn giảm thiểu (Mitigation); Giai đoạn chuẩn bị (Preparedness); Giai đoạn ứng phó (Response); Giai đoạn phục hồi (Recovery):

Như vậy có thể thấy, mặc dù có nhiều biến thể khác nhau đối với số giai đoạn trong quy trình quản lý thiên tai khép kín nhưng phiên bản phổ biến nhất là quy trình với 4 giai đoạn (minh họa trong Hình 2).

- Phòng ngừa/ Giảm thiểu (Mitigation): Bao gồm các biện pháp giảm thiểu được lồng ghép vào quy hoạch phát triển quốc gia và khu vực nhằm loại bỏ hoặc giảm thiểu xác suất xảy ra hiểm họa thiên tai trong tương lai và giảm thiểu tác động cũng như thiệt hại gây ra từ những hiểm họa không thể tránh khỏi.

- Chuẩn bị (Preparation): Bao gồm việc xây dựng kế hoạch hoặc sự chuẩn bị sẵn sàng ứng phó và phục hồi trước các tình huống khẩn cấp thông qua các chương trình tăng cường năng lực quản lý và kỹ thuật của các Chính phủ, tổ chức và cộng đồng. 
- Úng phó với thiên tai (Response): bao gồm các hành động thực hiện trong hoặc ngay sau tình huống khẩn cấp, bao gồm các nỗ lực cứu người và ngăn ngừa thiệt hại thêm về tài sản. Trọng tâm trong giai đoạn ứng phó là đáp ứng các nhu cầu cơ bản của người dân cho đến khi tìm được các giải pháp lâu dài và bền vững hơn.

- Phục hồi sau thiên tai (Recovery): bao gồm việc khôi phục, xây dựng lại khu vực bị ảnh hưởng đã được đánh giá và các nỗ lực ứng phó phù hợp đã được thực hiện trong giai đoạn ngay trong và sau thiên tai. Mục đích của giai đoạn này là khôi phục môi trường, kinh tế và xã hội để đưa cộng đồng bị ảnh hưởng trở lại trạng thái ban đầu và phát triển tái thiết hướng tới các điều kiện tốt hơn và bền vững hơn.

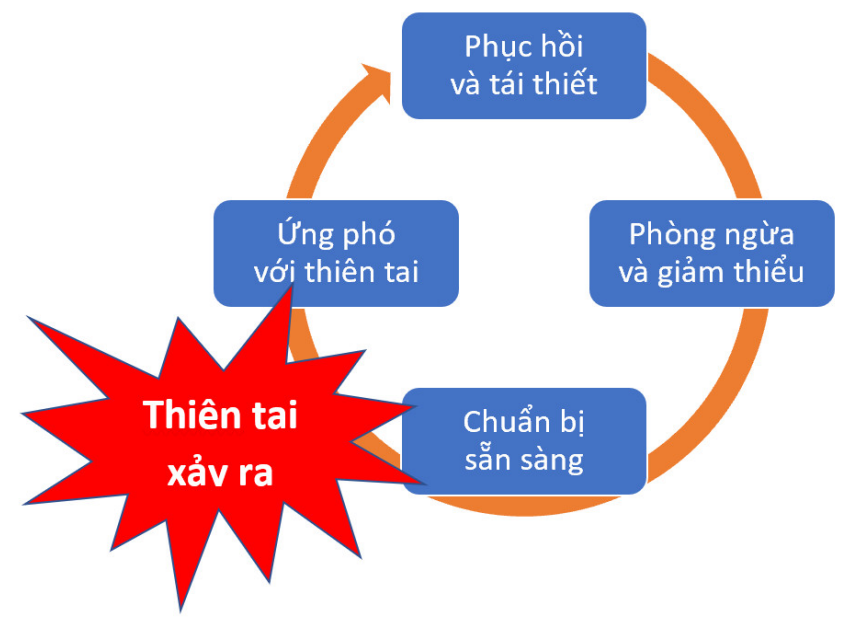

Hình 2. Quy trình quản lý thiên tai khép kín [6].

Bài báo này áp dụng quy trình quản lý thiên tai khép kín 4 bước của $\mathrm{ADB}$ để đánh giá hiện trạng và đóng góp của ngành công an đối với công tác ứng phó với biến đổi khí hậu (UPBĐKH), phòng chống thiên tai (PCTT) và tìm kiếm cứu nạn $(\mathrm{TKCN})$ quốc gia.

\section{Phương pháp nghiên cứu và thu thập số liệu}

\subsection{Phưong pháp nghiên cúu}

Việc đánh giá hiện trạng và đóng góp của ngành Công an cho công tác UPBĐKH, PCTT và $\mathrm{TKCN}$ được tiến hành theo quy trình 4 bước của $\mathrm{ADB}$, như sau:

- Giai đoạn phòng ngừa và giảm thiểu: là khoảng thời gian mà Chính phủ, các Bộ, ngành và địa phương xây dựng và thực hiện các hành động hàng năm. Trong đó, tập trung vào các hành động và biện pháp nhằm loại bỏ hoặc giảm thiểu xác suất xảy ra hiểm họa thiên tai trong tương lai và giảm thiểu tác động cũng như thiệt hại gây ra từ những hiểm họa không thể tránh khỏi.

- Giai đoạn chuẩn bị: là giai đoạn từ khi Chính phủ, các Bộ, ngành và địa phương xây dựng và thực hiện các hành động khi có các dự báo ngắn hạn liên quan đến thiên tai. Các hành động trong giai đoạn này sẽ tập trung nhiều vào việc xây dựng kế hoạch hoặc chuẩn bị sẵn sàng ứng phó và phục hồi trước các tình huống khẩn cấp.

- Giai đoạn ứng phó trong và ngay sau thiên tai: là giai đoạn từ khi Chính phủ, các Bộ, ngành, địa phương và cộng đồng thực hiện các hành động PCTT và $\mathrm{TKCN}$ trong và ngay sau khi thiên tai xảy ra. Các hành động chính tập trung vào các nỗ lực cứu người và ngăn ngừa thiệt hại thêm về tài sản.

- Giai đoạn phục hồi và tái thiết: là giai đoạn từ khi Chính phủ, các Bộ, ngành, địa phương và cộng đồng xây dựng và thực hiện các hành động khôi phục, xây dựng lại khu vực bị ảnh hưởng, cũng như tiếp tục các nỗ lực ứng phó phù hợp đã được thực hiện trong giai đoạn trên. 
Các tiêu chí được đánh giá theo 4 nhóm nội dung: (i) Cơ cấu tổ chức; (ii) Xây dựng và lập kế hoạch, (iii) Nguồn lực, và (iv) Trình độ và kỹ năng của lực lượng CAND tham gia công tác PCTT và TKCN [9].

\subsection{Thu thập số liệu}

Để phục vụ nghiên cứu, các phương pháp phỏng vấn bằng bảng hỏi và phỏng vấn sâu được sử dụng, cụ thể:

- Phỏng vấn bằng bảng hỏi: nghiên cứu sử dụng bảng hỏi để phỏng vấn và hỏi ý kiến của các cán bộ trong ngành Công an nhằm thu thập thông tin trực tiếp những cán bộ Công an thực hiện công tác PCTT và TKCN. Các nội dung phản ánh trong các mẫu phiếu điều tra này sau đó được mã hóa, tổng hợp, xử lý và đánh giá ý nghĩa thống kê của các số liệu thu thập được thông qua phần mềm Excel.

- Phỏng vấn sâu: Phương pháp phỏng vấn sâu được sử dụng nhằm hiểu sâu, hiểu kỹ về bản chất của các nguyên nhân dẫn đến những bất cập và thiếu sót trong công tác PCTT và TKCN của ngành Công an trong điều kiện BĐKH.

\section{Kết quả và thảo luận}

Trong mục này, bài báo trình bày kết quả đánh giá hiện trạng công tác UPBĐKH, PCTT và TKCN (sau đây gọi tắt là UPT) của ngành Công an dựa trên các tài liệu thu thập được và ý kiến của các cán bộ đang trực tiếp tham gia chỉ đạo và thực hiện các hoạt động này.

\subsection{Giai đoạn phòng ngùal giảm thiêu}

\subsubsection{Cơ cấu tổ chức}

Có 2 nội dung/ tiêu chí được phân tích và đánh giá, gồm: (1) Rà soát và cập nhật Hệ thống văn bản pháp quy có liên quan; (2) Đảm bảo sự thống nhất và thông suốt trong phân công, chỉ đạo và chỉ huy giữa các cấp/ ngành có liên quan từ trung ương đến địa phương và cấp cơ sở/cộng đồng;

Bộ Công an (BCA) đã ban hành một số văn bản pháp quy có liên quan đến lĩnh vực UPT cũng như đảm bảo công tác phân công, chỉ đạo và chỉ huy. Hàng năm, Bộ Công an xây dựng báo cáo đánh giá kết quả và khó khăn, hạn chế trong thực hiện UPT của năm trước và xây dựng kế hoạch công tác cho năm sau. Các nội dung về ứng phó với BĐKH và các tác động BĐKH luôn được lồng ghép và đánh giá đầy đủ trong các báo cáo và kế hoạch công tác này.

Ban Chỉ đạo U'PT của Bộ Công an hàng năm đều ban hành Kế hoạch hoạt động, trong đó, xác định rõ mục đích, yêu cầu, nhiệm vụ trọng tâm và phân công trách nhiệm cụ thể cho Công an các đơn vị, địa phương trong công tác UPT. Các đơn vị chức năng và Công an các địa phương đã cụ thể hóa các chỉ đạo của Đảng ủy Công an Trung ương, rà soát và bổ sung điều chỉnh cho phù hợp, thường xuyên đôn đốc kiểm tra việc thực hiện các phương án, quán triệt, nhất quán và thực hiện nghiêm túc phương châm "4 tại chỗ" và "3 sẵn sàng".

Như vậy, trong giai đoạn phòng ngừa và giảm thiểu, các nội dung liên quan đến cơ cấu tổ chức, hệ thống văn bản pháp quy nhằm thực hiện UPT đã được Bộ Công an quan tâm và văn bản hóa. Tuy nhiên, các văn bản thường tập trung vào phân công các đơn vị thực hiện theo chức năng nhiệm vụ được giao, trong khi đó, nhiều trường hợp, điều kiện hiện tại của các đơn vị chức năng không thực sự thuận lợi để thực hiện theo chỉ đạo. Do đó, hiệu quả của công tác phòng ngừa giảm thiểu thiệt hại của thiên tai thông qua các chỉ đạo còn một số bất cập.

Các ý kiến của cán bộ chiến sĩ $(\mathrm{CBCS})$ và cán bộ quản lý tham gia trả lời khảo sát cơ bản có nhiều điểm trùng hợp đánh giá trên, cụ thể:

“Trong những năm gần đây, đã có nhiều văn bản chỉ đạo và điều hành của Bộ về các nội dung liên quan đến công tác PCTT và TKCN trong điều kiện $\mathrm{B} Đ K H$, Bộ đã có nhiều văn bản 
chỉ đạo cụ thể hàng năm, cũng như những cập nhật và bổ sung theo các chỉ đạo mới của Chính phủ. Tuy nhiên, hiện nay một số đơn vị đang gặp nhiều khó khăn...” [10].

"Công tác đào tạo, tập huấn, huấn luyện cho CBCS Công an cấp cơ sở chưa được thực hiện thường xuyên, mới tập trung thực hiện tập huấn đối với Lãnh đạo cấp Phòng và cán bộ được giao giúp việc Ban chỉ huy U’PT Công an các tỉnh, thành phố trực thuộc Trung ương; đề xuất thường xuyên tổ chức bồi dưỡng, đào tạo, tập huấn, huấn luyện kỹ nghiệp vụ, kỹ năng PCTT\&TKCN cho Công an cấp tỉnh, cấp huyện và cấp xã để thực hiện công tác PCTT và TKCN có hiệu quả cao hơn” [10]. “... Cần phải có nguồn kinh phí và chế độ chính sách phù hợp để hỗ trợ cán bộ chiến sĩ tực tiếp tham gia ứng phó và khắc phục hậu quả do thiên tai gây ra” [10] Kết quả đánh giá được tổng kết trong Bảng 1 .

Bảng 1. Đánh giá sơ bộ về cơ cấu tổ chức trong giai đoạn phòng ngừa/giảm thiểu.

\begin{tabular}{|c|c|c|}
\hline Nhóm & Tiêu chí/nội dung & Đánh giá so’ bộ \\
\hline & $\begin{array}{l}\text { - Hệ thống văn bản pháp quy có liên quan được rà soát } \\
\text { và câp nhât }\end{array}$ & Đảm bảo \\
\hline $\begin{array}{l}\text { Cơ } \\
\text { cấu tổ } \\
\text { chức }\end{array}$ & $\begin{array}{l}\text { - Đảm bảo sự thống nhất và thông suốt trong chỉ đạo } \\
\text { và chỉ huy giữa các cấp/ngành có liên quan từ Trung } \\
\text { ương đến địa phương/cơ sở } \\
\text { - Rà soát kiện toàn tô chức } \mathrm{PCTT} \text { và } \mathrm{TKCN} \text { hàng năm }\end{array}$ & $\begin{array}{l}\text { Đảm bảo, tuy nhiên còn một số hạn chế } \\
\text { trong thực hiện, kết quả mang lại tại các } \\
\text { cấp ở địa phương, cơ sở } \\
\text { Để đảm bảo thực hiện tốt công tác chỉ đạo, } \\
\text { cần rà soát kiện toàn tố chức. }\end{array}$ \\
\hline
\end{tabular}

\subsubsection{Xây dựng và lập kế hoạch}

Để đánh giá hiệu quả công tác xây dựng và thực hiện các kế hoạch hàng năm về UPT, 03 nội dung/tiêu chí được đề xuất xem xét và đánh giá như sau: (1) Mức độ cập nhật các thông tin và tính sát thực của các kế hoạch được xây dựng; (2) Lồng ghép các nội dung liên quan đến UPT trong các kế hoạch, quy hoạch phát triển; (3) Kế hoạch thông tin, tuyền thông và tổ chức các lớp đào tạo nâng cao trình độ nguồn nhân lực của lực lượng Công an nhân dân thực hiện UPT.

Tại các cấp, thông tin về thực hiện UPT luôn được lồng ghép và cập nhật vào các kế hoạch của năm sau. Tuy nhiên, công tác xây dựng và lập kế hoạch vẫn chưa thực sự sát với tình hình thực tế tại một số địa phương, thiếu sự thống nhất đồng bộ. Các văn bản pháp quy, luật và quy định các cấp có liên quan về UPT đã được chủ động lồng ghép để tổ chức quán triệt, phổ biến đến cán bộ chiến sĩ (CBCS). Tuy nhiên, các kết quả và hiện trạng công tác lồng ghép chưa thực sự rõ ràng. Kết quả đánh giá được tổng kết trong Bảng 2.

Bảng 2. Đánh giá sơ bộ về xây dựng và lập kế hoạch trong giai đoạn phòng ngừa/giảm thiểu.

\begin{tabular}{|c|c|c|}
\hline Nhóm & Tiêu chí/nội dung & Đánh giá so’ bộ \\
\hline & $\begin{array}{l}\text { - Mức độ cập nhật các thông tin và tính sát thực của các kế } \\
\text { hoach được xây dưng }\end{array}$ & $\begin{array}{l}\text { Các thông tin được cập nhật liên } \\
\text { tuc }\end{array}$ \\
\hline $\begin{array}{l}\text { Xây } \\
\text { dựng và } \\
\text { lập kế }\end{array}$ & $\begin{array}{l}\text { - Lồng ghép các nội dung liên quan đến UPT trong các kế } \\
\text { hoạch, quy hoạch phát triển ngành (gồm } 6 \text { nội dung quy } \\
\text { định trong Khoản } 5 \text { Điều } 15 \text { của Luật PCTT) }\end{array}$ & $\begin{array}{l}\text { Đã được từng bước thực hiện, tuy } \\
\text { chưa có các báo cáo kết quả rõ } \\
\text { ràng và cụ thể }\end{array}$ \\
\hline hoạch & $\begin{array}{l}\text { - Kế hoạch thông tin, tuyền thông và tổ chức tập huấn, huấn } \\
\text { luyện, diễn tập và đào tạo nâng cao trình độ nguồn nhân } \\
\text { lực của lực lương CAND thực hiện UPT }\end{array}$ & $\begin{array}{l}\text { Được quan tâm và thực hiện trong } \\
\text { báo cáo hàng năm về UPT }\end{array}$ \\
\hline
\end{tabular}

\subsubsection{Nguồn lực}

Nghiên cứu tập trung vào 06 nội dung để đánh giá công tác đảm bảo nguồn lực (Bảng 3). Trong đó bao gồm 3 nguồn lực chính là nguồn nhân lực, nguồn lực về cơ sở vật chất và tài chính.

Về nguồn nhân lực: kết quả điều tra và phân tích cho thấy số lượng CBCS qua đào tạo, tập huấn của ngành Công an tham gia công tác U'PT là tương đối cao (gần $80 \%$ ), nhưng lực 
lượng qua đào tạo hệ trung và sơ cấp còn chiếm tỷ lệ lớn $(35 \%)$. Điều đó cho thấy chất lượng của CBCS tham gia công tác UPT còn thấp, khó có thể đáp ứng nhiệm vụ đặt ra trong thời gian sắp tới.

Nhận thức được tầm quan trọng trong thực hiện "4 tại chỗ" trong thực hiện công tác UPT, ngành Công an đã tập trung và chỉ đạo theo hướng huy động nguồn nhân lực tại chỗ. Để có thể hoàn thành tốt công tác UPT, cần có những cơ chế, chính sách hỗ trợ cũng như có những chương trình, dự án phát triển nâng cao nguồn nhân lực đặc biệt là lực lượng thường trực chuyên trách, đầu tư cơ sở vật chất, phương tiện, trang thiết bị kỹ thuật và công tác tổ chức cán bộ để ngành Công an đáp ứng được yêu cầu nhiệm vụ ngày càng cao của công tác UPT.

Nhằm khuyến khích, động viên cán bộ, chiến sĩ và các lực lượng an tâm làm nhiệm vụ, Bộ Công an đã có các văn bản, quy định, hướng dẫn cụ thể, bảo đảm chế độ, chính sách phù hợp cho các lực lượng làm nhiệm vụ U'PT. Tuy nhiên, qua nghiên cứu ra soát một số văn bản này đã được ban hành từ những năm 2008 về trước và đang tiếp tục được áp dụng.

Về cơ cấu tổ chức: Việc chỉ định đơn vị thường trực công tác UPT tại Ban Chỉ huy UPT Công an các địa phương còn chưa rõ ràng, thống nhất, không có cán bộ chuyên trách, chỉ có cán bộ kiêm nhiệm nên hiệu quả công việc chưa cao, chưa đạt yêu cầu.

Về chế độ chính sách: Chưa có quy định rõ ràng về lực lượng chuyên trách, dự bị, xung kích và kiêm nhiệm; có nhưng chưa đầy đủ về chế độ chính sách, bồi dưỡng cho các lực lượng dự bị, xung kích, kiêm nhiệm tham gia UPT. Chưa có quy định cụ thể về đào tạo, cấp chứng chỉ huấn luyện kỹ năng nghiệp vụ chuyên sâu về công tác UUPT, hướng dẫn sử dụng thuần thục các trang thiết bị, phương tiện cứu hộ, cứu nạn trong thiên tai, sự cố nghiêm trọng cho các lực lượng. Chưa có chính sách khuyến khích các hoạt động khoa học công nghệ, thu hút đầu tư, hợp tác quốc tế, huy động nguồn lực nghiên cứu ứng dụng khoa học công nghệ trong UPT.

Về phương tiện trang thiết bị: Chưa có tiêu chuẩn định mức trang bị cho các lực lượng thường trực chuyên trách, xung kích, dự bị tham gia UPT từ cấp tiểu đội, trung đội đến đại đội... Qua điều tra đánh giá từ các đơn vị địa phương, gần như $100 \%$ các phương tiện, trang thiết bị kỹ thuật đang được sử dụng tuy nhiên mới chỉ đáp ứng được khoảng $60 \%$ nhu cầu của công tác UPT. Cá biệt có những loại phương tiện chưa được đầu tư như xe lưỡng cư tìm kiếm cứu nạn, trạm công tác di động. Đây là một trong những nguyên nhân gây khó khăn rất lớn cho ngành Công an trong công tác UPT khi có thiên tai, sự cố xảy ra.

Hệ thống các cơ sở nghiên cứu, sản xuất của khu công nghiệp an ninh có quy mô nhỏ, chưa tương xứng với yêu cầu phục vụ chiến đấu và xây dựng lực lượng của ngành Công an trong giai đoạn mới: Các sản phẩm phương tiện kỹ thuật nghiệp vụ, công cụ hỗ trợ trang bị cho các đơn vị, địa phương còn rất thiếu về số lượng và chất lượng chưa cao; cơ sở vật chất, trang thiết bị và trình độ công nghệ của đa số các cơ sở nghiên cứu, sản xuất có hàm lượng công nghệ cao thấp. Mạng lưới Kho do Bộ Công an quản lý hiện nay bộc lộ nhiều hạn chế. Các điểm kho nhỏ lẻ phân tán, xa các điểm xung yếu về thiên tai, bão lũ, thậm chí, dễ bị chia cắt, cô lập khi có thiên tai, bão, lũ xảy ra. Công nghệ bảo quản lạc hậu; trang thiết bị kho thô sơ, phân bổ lực lượng chưa hợp lý, nơi thừa, nơi thiếu; chưa đáp ứng tốt nhất yêu cầu nhiệm vụ trong các tình huống đột xuất của Nhà nước và ngành Công an. Một trong những nguyên nhân hạn chế trên là do việc đầu tư xây dựng hệ thống kho chưa theo quy hoạch tổng thể của toàn hệ thống [11].

Bảng 3. Đánh giá sơ bộ về nội dung liên quan đến nguồn lực, giai đoạn phòng ngừa/giảm thiểu.

\begin{tabular}{|c|c|c|}
\hline Nhóm & Tiêu chí/nội dung & Đánh giá sơ bộ \\
\hline $\begin{array}{l}\text { Nguồn } \\
\text { lực }\end{array}$ & $\begin{array}{l}\text { - Định kỳ thực hiện sửa chữa, bảo dưỡng và đầu } \\
\text { tư mới nhằm đảm bảo nguồn lực (Phương tiện, } \\
\text { trang thiết bị, nhu yếu phẩn, các công trình } \\
\text { PCTT và nguồn lực khác - đảm bảo nguyên tắc } \\
\text { "4 tại chô̂"); } \\
\text { - Định kỳ thực hiện sửa chữa, bảo dưỡng, đầu tư } \\
\text { mới trang thiết bị của hệ thống thông tin liên } \\
\text { lạc, hệ thống cảnh báo và hệ thống quản lý }\end{array}$ & $\begin{array}{l}\text { Luôn được đề cập trong kế hoạch hàng năm, tuy } \\
\text { nhiên vần còn thiếu nhiều vế số lượng và chất } \\
\text { lượng chưa cao; cơ sở vật chất, trang thiết bị và } \\
\text { trình độ công nghệ còn hạn chế. } \\
\text { Luôn được đề cập trong kế hoạch hàng năm }\end{array}$ \\
\hline
\end{tabular}




\begin{tabular}{|c|c|c|}
\hline Nhóm & Tiêu chí/nội dung & Đánh giá so bộ \\
\hline & $\begin{array}{l}\text { thông tin } \\
\text { - Hỗ trợ thực hiện xây dựng mới và nâng cấp trụ } \\
\text { sở, nơi làm việc của hệ thống Công an cấp xã } \\
\text { kết hợp sử dụng làm địa điểm sơ tán dân khi có } \\
\text { sự cố, thiên tai; } \\
\text { - Đầu tư mới nhằm đảm bảo nguồn lực phương } \\
\text { tiện, trang thiết bị thiết yếu cho lực lượng Công } \\
\text { an cấp xã theo phương châm "4 tại chồ"; } \\
\text { - Quan điểm hướng về cơ sở để đầu tư. } \\
\text { - Kế hoạch/dự kiến Phân bổ nguồn lực tài chính } \\
\text { cho các hoạt động hàng năm } \\
\text { - Phát triển và nâng cao chất lượng năng lực } \\
\text { CBCS cũng như nâng cao khả năng huy động } \\
\text { lực lượng CAND thực hiện UPT. } \\
\text { - Thực hiện đãi ngộ cán bộ chiến sĩ thực hiện } \\
\text { nhiệm vụ UPT. }\end{array}$ & 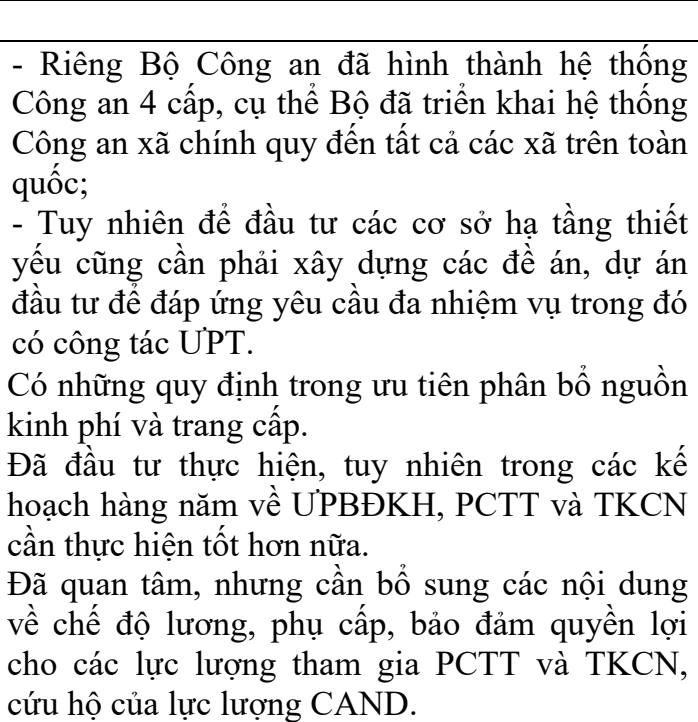 \\
\hline
\end{tabular}

Về nguồn lực tài chính, Bộ Công an luôn có chính sách ưu tiên bố trí kinh phí và trang cấp, bổ sung phương tiện, vật tư phục vụ UPT. Các đơn vị liên quan chủ động đề xuất lãnh đạo Bộ điều chỉnh phân bổ ngân sách, bổ sung danh mục và trang cấp cho Công an địa phương, tranh thủ nguồn lực hỗ trợ từ chính quyền địa phương và xã hội hóa. Đánh giá từ thực tế năm 2020 với tình hình thiên tai liên tục, Bộ Công an đã chỉ đạo xuất cấp hết các vật tư, phương tiện phục vụ cho công tác PCTT và $\mathrm{TKCN}$, cứu hộ, qua đây cần nghiêm túc đánh giá công tác đầu tư bảo đảm còn chưa đầy đủ, chưa nói đến đầu tư dự phòng, với các điều kiện và yêu cầu cấp thiết trên Bộ Công an cần tập trung xây dựng các đề án dự án đầu tư mua sắm và trang cấp để phục vụ công tác chiến đâu, $\mathrm{PCTT}$ và $\mathrm{TKCN}$. Kết quả đánh giá được trình bày trong Bảng 3 .

\subsubsection{Trình độ và kỹ năng}

Các nội dung liên quan đến việc phát triến trình độ khoa học công nghệ cho lực lượng CAND đã được đặt ra và thực hiện trong Khung chương trình hành động U'PBĐKH giai đoạn 2021-2030, tầm nhìn 2050 được ban hành ngày 13/01/2020 theo Quyết định số 270/QĐ-BCAH06. Trong đó, có đề cập đến hoạt động nghiên cứu khoa học và phát triển công nghệ, tăng cường hợp tác quốc tế để áp dụng các thành tựu khoa học công nghệ bảo vệ môi trường nhằm UPBĐKH, giảm thiểu tác động xấu ảnh hưởng đến hoạt đồng của công tác Công an.

Việc đầu tư hiện đại hóa trang bị, phương tiện PCTT và $\mathrm{TKCN}$ là chủ trương và hướng đi đúng của Ban Chỉ đạo UPT Bộ Công an trong công tác tham mưu cho lãnh đạo Bộ tổ chức thực hiện, nâng cao năng lực, hiệu quả công tác phòng, chống, ứng phó thiên tai, và tìm kiếm, cứu nạn trước những diễn biến phức tạp của tình hình an ninh phi truyền thống hiện nay. Thực tế, việc trang bị phương tiện PCTT và $\mathrm{TKCN}$, cứu hộ vẫn còn chậm được bổ sung, phát triển, nhất là các trang thiết bị chuyên dụng, hiện đại.

Để có thể có được những nhận định về trình độ và kỹ năng phục vụ công tác U’PT trong giai đoạn phòng ngừa và giảm thiểu, một số đánh giá về hiện trạng trình độ chuyên môn của các $\mathrm{CBCS}$ được đề cập.

Trong đó, tại cấp địa phương, 55\% cán bộ chiến sĩ tham gia nhiệm vụ chung được đào tạo chuyên ngành Cảnh sát, $14 \%$ cán bộ chiến sĩ đào tạo chuyên ngành An ninh, $12 \%$ được đào tạo PCCC và $3 \%$ đào tạo cứu nạn, cứu hộ. Ngoài ra chỉ có $7 \%$ lực lượng được đào tạo chuyên ngành hậu cần, kỹ thuật.

- Tham gia với công tác ứng phó với $\mathrm{BĐKH:} \mathrm{Có} \mathrm{60 \%} \mathrm{lực} \mathrm{lượng} \mathrm{Công} \mathrm{an} \mathrm{tham} \mathrm{gia} \mathrm{có}$ nghiệp vụ cảnh sát, $17 \%$ được đào tạo chuyên ngành $\mathrm{PCCC}, 8 \%$ chuyên ngành $\mathrm{An}$ ninh và $5 \%$ cứu nạn cứu hộ, $4 \%$ đào tạo Hậu cần - kỹ thuật. 
- Tham gia công tác PCTT: Có 54\% cán bộ chiến sĩ được đào tạo chuyên ngành Cảnh sát, $13 \%$ là $\mathrm{PCCC}, 12 \%$ chuyên ngành An ninh và $9 \%$ có nghiệp vụ Hậu cần - kỹ thuật.

- Tham gia công tác TKCN: Có 57\% lực lượng Công an được đào tạo chuyên ngành Cảnh sát, $24 \%$ là $\mathrm{PCCC}, 5 \%$ Hậu cần - kỹ thuật và $3 \%$ đào tạo chuyên ngành An ninh [12]. Nhìn chung các lực lượng tham gia công tác UPBĐKH, PCTT và TKCN của ngành Công an chủ yếu được đào tạo chuyên ngành Cảnh sát bình quân chiếm trên $56 \%$, An ninh gần $9 \%$, PCCC gần $18 \%$, cứu nạn, cứu hộ $4,5 \%$ và Hậu cần - kỹ thuật trên $6 \%$. Do đó để đáp ứng được nhu cầu nhiệm vụ ngày càng cao, việc phát triển các cơ sở đào tạo các lĩnh vực nêu trên về chất lượng cũng như số lượng là một trong những nhiệm vụ hàng đầu của ngành Công an nói chung và của các cơ sở đào tạo của ngành Công an nói riêng. Bộ Công an đã thực hiện nhiều biện pháp liên quan đến hoạt động truyền thông và nâng cao năng lực của lực lượng CAND. Kết quả đánh giá được trình bày trong Bảng 4 .

Bảng 4. Đánh giá sơ bộ về nội dung liên quan đến trình độ và kỹ năng, giai đoạn phòng ngừa/giảm thiểu.

\begin{tabular}{|c|c|c|}
\hline Nhóm & Tiêu chí/nội dung & Đánh giá so bộ \\
\hline $\begin{array}{ll}\text { Trình } & \text { độ } \\
\text { và } & \text { kỹ } \\
\text { năng } & \end{array}$ & $\begin{array}{l}\text { - Đẩy mạnh áp dụng KHCN trong chỉ huy, điều hành và phối hợp } \\
\text { với các ngành/đơn vị có liên quan khác trong thực hiện UPT } \\
\text { - Đảm bảo hoạt động diến tập phù hợp với các cẩp độ rủi ro của } \\
\text { sự cố, thiên tai } \\
\text { - Hoạt động truyền thông và nâng cao năng lực của lực lượng } \\
\text { CAND trong PCTT và TKCN. }\end{array}$ & $\begin{array}{l}\text { Đã được quan tâm và } \\
\text { từng bước thực hiện } \\
\text { Đã được quan tâm và } \\
\text { từng bước thực hiện } \\
\text { Đã được quan tâm và } \\
\text { từng bước thực hiện }\end{array}$ \\
\hline
\end{tabular}

Về công tác tuyên truyền, đã có nhiều tài liệu, sổ tay kiến thức, kỹ năng $\mathrm{CNCH}$ cơ bản như: Kỹ năng xử lý các sự cố, tai nạn thường gặp, tuyên truyền bằng pano, áp phích, tờ rơi,... chủ động phối hợp với cá cơ quan, đài báo trong và ngoài lực lượng như Đài truyền hình Việt Nam, Thông tấn xã, Kỹ thuật số VTV, ANTV, VOV, Cổng thông tin điện tử Chính phủ, Tạp chí $\mathrm{PCCC}, \ldots$ thường xuyên tuyên truyền và phổ biến kiến thức về $\mathrm{BĐKH}$, thiên tai, cũng như những văn bản quy phạm pháp luật về công tác U'PBĐKH, PCTT và TKCN. Nội dung tuyên truyền bao gồm cả những ví dụ điển hình, những giải thích và trao đổi nhằm thuyết phục và luận giải những thông tin trái chiều [13].

\subsection{Giai đoạn chuẩn bi}

\subsubsection{Cơ cấu tổ chức}

Ban Chỉ đạo UPBĐKH, PCTT và TKCN Bộ Công an thường xuyên đôn đốc Công an các đơn vị, địa phương báo cáo tình hình triển khai công tác ứng phó với các đợt bão, lũ và thiên tai khác nhằm tập hợp báo cáo lãnh đạo Bộ Công an để có biện pháp xử lý kịp thời. Tổ chức thực hiện nghiêm túc $24 / 24$ trong ngày theo dõi diễn biến của thiên tai, bão, mưa lũ; ban hành nhiều công điện kịp thời chỉ đạo Công an các đơn vị, địa phương trong cả nước. Tập trung đảm bảo hệ thống thông tin liên lạc hoạt động thông suốt giữa cơ quan Bộ và Công an các đơn vị, địa phương. Trên thực tế Bộ Công an đã và đang nghiên cứu ban hành các phương án Chi viện lực lượng, phương tiện của ngành Công an tham gia ứng phó với bão mạnh đổ bộ vào Việt Nam. Trong đó xác định rõ vai trò, chức năng, và nhiệm vụ cụ thể của từng đơn vị, địa phương. Ngoài ra, Bộ Công an cũng phối hợp cùng các bên liên quan trong chủ động rà soát, xây dựng phương án ứng phó đối với từng loại hình thiên tai, sự cố cơ bản có thể xảy ra trên địa bàn và thuộc phạm vi quản lý; sẵn sàng vật tư, trang thiết bị, nhân lực để ứng phó kịp thời.

Như vậy, có thể nhận thấy Bộ Công an đã thực hiện tương đối tốt công tác quản lý và cơ cấu tổ chức trong giai đoạn chuẩn bị, khi có các thông tin dự báo ngắn hạn và trung hạn về thiên tai, các hiện tượng thời tiết cực đoan,... Kết quả đánh giá được trình bày trong Bảng 5 . 
Bảng 5. Đánh giá sơ bộ về nội dung liên quan đến cơ cấu tổ chức thực hiện, giai đoạn chuẩn bị.

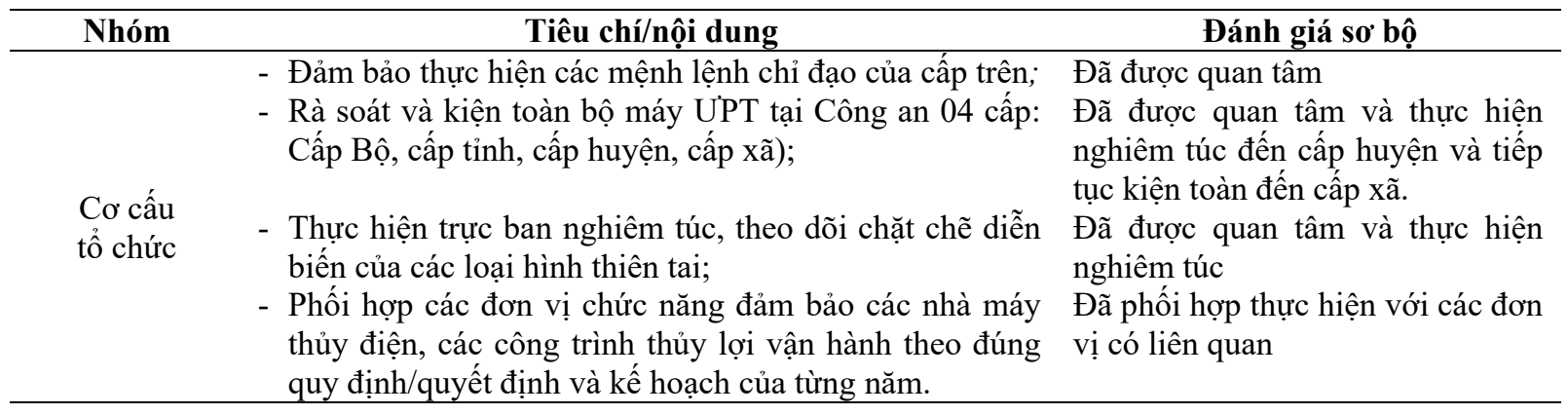

\subsubsection{Xây dựng và lập kế hoạch}

Các đơn vị được phân công triển khai hoạt động U’PT của Bộ Công an đã luôn thực hiện điều chỉnh các phương án PCTT, sơ tán, tìm kiếm cứu nạn, cứu hộ phù hợp với diễn biến của thiên tai và các hiện tượng thời tiết cực đoan. Trong Sổ tay hướng dẫn thực hiện xây dựng các phương án ứng theo các loại hình thiên tai tương ứng với cấp độ rủi ro thiên tai, các nội dung cần phải thực hiện điều chỉnh cho phù hợp với điều kiện thực tế đã được xác định rõ. Căn cứ vào các nội dung của Ban chỉ đạo trung ương về PCTT [11], ngành Công an kết hợp cùng các đơn vị liên quan xây dựng, lên kế hoạch và điều chỉnh các phương án ứng phó cho một số nội dung tương ứng với các loại hình thiên tai cụ thể. Trong đó, nêu rõ cấp độ rủi ro của từng loại thiên tai, đối tượng bị ảnh hưởng và phương án ứng phó cần thiết được triển khai.

Như vậy có thể thấy, các hoạt động xây dựng, thực hiện và điều chỉnh các kế hoạch trong UPT của Bộ Công an cũng đã được thực hiện thông suốt và đầy đủ. Tuy nhiên, các thông tin về nguồn ngân sách dự kiến cho các công tác triển khai còn chưa mở, có thể tạo ra những bất lợi trong công tác xây dựng và điều chỉnh các phương án, đặc biệt tại các địa phương không có nhiều nguồn lực dự trữ. Kết quả đánh giá được trình bày trong Bảng 6 .

Bảng 6. Đánh giá sơ bộ về nội dung liên quan đến xây dựng và lập kế hoạch, giai đoạn chuẩn bị.

\begin{tabular}{|c|c|c|}
\hline Nhóm & Tiêu chí/nội dung & Đánh giá so bộ \\
\hline \multirow{3}{*}{$\begin{array}{l}\text { Xây dựng và } \\
\text { lập kế hoạch }\end{array}$} & $\begin{array}{l}\text { - Xây dựng, thường xuyên cập nhật các kế hoạch và phương } \\
\text { án cụ thề về nguồn lực, phân công và phối hợp thực hiện }\end{array}$ & Đươc quan tâm đặc biệt \\
\hline & $\begin{array}{l}\text { - Phối hợp xây dựng các phương án phòng chống liên quan } \\
\text { đến các rủi ro thứ cấp }\end{array}$ & $\begin{array}{l}\text { Được quan tâm và thực } \\
\text { hiện }\end{array}$ \\
\hline & $\begin{array}{l}\text { - Lập kế hoạch về ngân sách và nguồn tài chính và xây dựng } \\
\text { các phương án huy động kinh phí cho các hoạt động ƯPT }\end{array}$ & $\begin{array}{l}\text { Nguồn lực hạn chế, sử } \\
\text { dụng kinh phí chi thường } \\
\text { xuyên }\end{array}$ \\
\hline
\end{tabular}

\subsubsection{Nguồn lực}

Trong giai đoạn chuẩn bị, có 3 nội dung chính cần được tiến hành đánh giá về hiệu quả và đóng góp của ngành Công an cùng các hoạt động chung của Quốc gia bao gồm: (1) Khả năng đảm bảo nguồn lực (phương tiện, trang thiết bị, nhu yếu phẩm, các công trình PCTT và nguồn lực khác, đảm bảo nguyên tắc "4 tại chỗ"); (2) Khả năng huy động lực lượng CAND thực hiện UPT; (3) Đảm bảo hoạt động của hệ thống thông tin liên lạc, cảnh bảo và quản lý thông tin [11].

Trong những năm qua Đảng ủy Công an Trung ương và lãnh đạo Bộ Công an đã quan tâm và chỉ đạo quyết liệt công tác ƯPT trong toàn lực lượng Công an. Chủ động tổ chức kiểm tra đôn đốc công tác ƯPT của các đơn vị, địa phương, đặc biệt tại những địa bàn trọng điểm về bão, lũ; rà soát, thống kê, đánh giá thực lực vật tư phương tiện PCTT và TKCN toàn lực lượng; kịp thời trang cấp và bổ sung kinh phí phục vụ yêu cầu "4 tại chỗ" cho các đơn vị, địa phương trước mùa mưa bão, do đó, công tác ứng phó với thiên tai đã chủ động hơn và có 
nhiều chuyển biến tích cực góp phần hạn chế thiệt hại về người và tài sản do thiên tai, sự cố gây ra.

Tuy vậy, ngành Công an nhất là ở đơn vị, địa phương nhiều nơi vẫn chưa đáp ứng được yêu cầu hiện tại, phương án PCTT và TKCN ở một số nơi vẫn chưa sát thực tế, công tác chuẩn bị theo phương châm "4 tại chỗ" chưa thực sự được quan tâm đúng mức, thiếu phương tiện, thiết bị phục vụ PCTT nên hiệu quả ứng phó, xử lý, khắc phục hậu quả thiên tai chưa cao. Ở một số địa phương, mặc dù các kế hoạch và phương án đã được xây dựng và điều chỉnh, song công tác huy động nguồn lực vẫn chưa hoàn chỉnh, thiếu tính thống nhất, chưa mang tính chuyên nghiệp. Các phương tiện chuyên dùng, đặc chủng chưa đủ mạnh để chủ động ứng phó với các tình huống thiên tai xảy ra. Kết quả đánh giá được trình bày trong Bảng 7.

Bảng 7. Đánh giá sơ bộ về nội dung liên quan đến chuẩn bị nguồn lực, giai đoạn chuẩn bị.

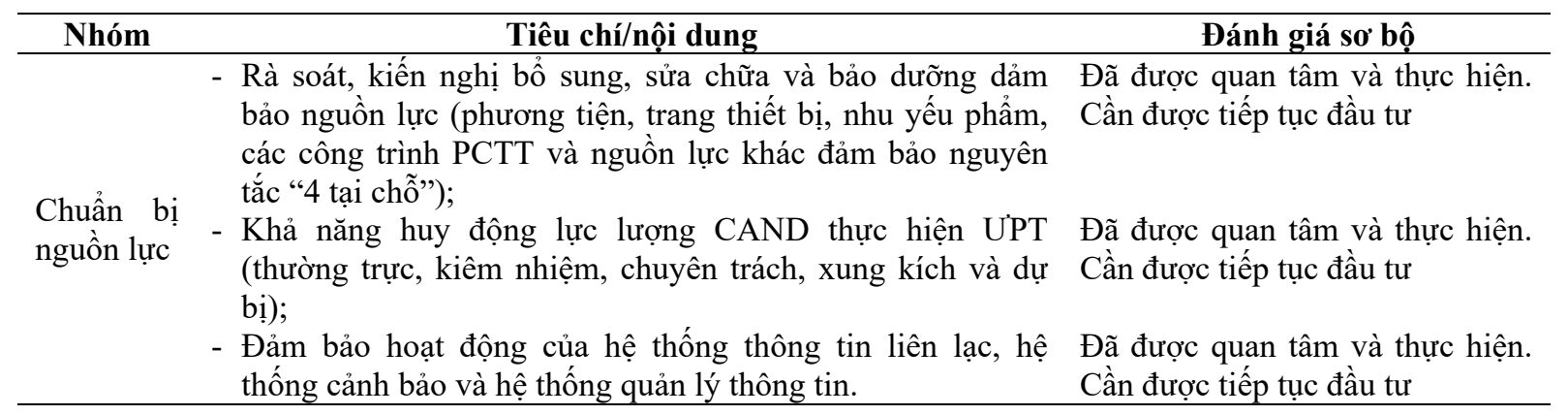

\subsubsection{Trình độ và kỹ năng}

Các kết quả của hoạt động UPBĐKH, PCTT và TKCN của Bộ Công an là không thể phủ nhận, tuy nhiên Bộ Công an cũng đã chỉ ra các thiết hụt về mặt trình độ và kỹ năng của các CBCS. Kết quả đánh giá được trình bày trong Bảng 8 .

Bảng 8. Đánh giá sơ bộ về nội dung liên quan đến chuẩn trình độ và kỹ năng, giai đoạn chuẩn bị.

\begin{tabular}{|c|c|c|}
\hline Nhóm & Tiêu chí/nội dung & Đánh giá sơ bộ \\
\hline & $\begin{array}{l}\text { - Khả năng tiếp nhận và xử lý các thông tin } \\
\text { cảnh báo từ cộng đồng và các tổ chức/đơn } \\
\text { vị có liên quan }\end{array}$ & $\begin{array}{l}\text { Thường được giao cho các CBCS có kinh } \\
\text { nghiệm thực tế chuẩn bị (Giao cho bộ phận } \\
\text { Tham mưu; Hậu cần; Giao thông, Cơ động }\end{array}$ \\
\hline $\begin{array}{l}\text { Trình độ và } \\
\text { kỹ năng }\end{array}$ & $\begin{array}{l}\text { - Khả năng tiếp nhận, phán đoán tình hình và } \\
\text { phản ứng phù hợp kịp thời với các thông tin } \\
\text { dự báo về thiên tai }\end{array}$ & $\begin{array}{l}\text { PCCC thực hiện) } \\
\text { Thường được giao cho các CBCS có kinh } \\
\text { nghiệm thực tế chuẩn bị (Giao cho bộ phận } \\
\text { Tham mưu; Hậu cần; Giao thông, Cơ động } \\
\text { PCCC thực hiện) }\end{array}$ \\
\hline
\end{tabular}

\subsection{Giai đoạn úng phó trong và ngay sau thiên tai}

\subsubsection{Cơ cấu tổ chức}

Trong mục này, việc đánh giá hiện trạng, hiệu quả đóng góp của lực lượng CAND trong thực hiện các giải pháp của cả nước nhằm thực hiện nhiệm vụ ƯPT được dựa trên 3 tiêu chí: (1) Ban hành kịp thời, chính xác các công điện, mệnh lệnh nhằm thực hiện hoạt động UPT;

(2) Kết hợp và huy động các nguồn lực và các đơn vị có liên quan thực hiện công tác UPT;

(3) Khả năng phản ứng nhanh và chủ động trong triển khai các hành động UPT.

Để có thể có những hành động phù hợp và kịp thời với những diễn biến phức tạp của thời tiết và những thiệt hại tại các đơn vị, địa phương, Bộ Công an luôn sát sao và ban hành các Công điện chỉ đạo việc thực hiện các hoạt động PCTT và TKCN. Công tác huy động lực lượng trong và ngay sau thiên tai và sự cố luôn được thực hiện nghiêm túc và bài bản. 
Nhìn chung trong thời gian vừa qua, công tác UPBĐKH, PCTT và $\mathrm{TKCN}$ đã được ngành Công an triển khai quyết liệt và đã có những kết quả nhất định, thiệt hại về người, tài sản đã giảm nhưng vẫn còn ở mức cao [13-16]. Kết quả đánh giá được tổng kết trong Bảng 9.

Bảng 9. Đánh giá sơ bộ về nội dung liên quan đến cơ cấu tổ chức, giai đoạn ứng phó trong và sau thiên tai.

\begin{tabular}{|c|c|c|}
\hline Nhóm & Tiêu chí/nội dung & Đánh giá sơ bộ \\
\hline $\begin{array}{l}\text { Cơ cấu } \\
\text { tổ chức }\end{array}$ & $\begin{array}{l}\text { - Ban hành kịp thời và chính xác các công điện, mệnh } \\
\text { lệnh nhằm thực hiện các hoạt động PCTT và TKCN; } \\
\text { - Kết hợp và huy động các nguồn lực và các đơn vị có } \\
\text { liên quan thực hiện công tác PCTT và TKCN; } \\
\text { - Khả năng phản ứng nhanh và chủ động trong triển } \\
\text { khai các hành động PCTT và TKCN (mức độ phù } \\
\text { hợp và kịp thời của các quyết định chỉ huy điều hành } \\
\text { ứng phó). }\end{array}$ & $\begin{array}{l}\text { Đã thực hiện và đảm bảo tốt các } \\
\text { yêu cầu của thực tế; } \\
\text { Đã được quan tâm và thực hiện } \\
\text { nghiêm túc. Đã góp phần không } \\
\text { nhỏ và giảm các mức độ thiệt hại } \\
\text { người và của tại các địa phương } \\
\text { Đã thực hiện và đảm bảo tốt các } \\
\text { yêu cầu của thực tế. }\end{array}$ \\
\hline
\end{tabular}

\subsubsection{Nguồn lực}

Việc đảm bảo nguồn lực trong giai đoạn này đóng vai trò then chốt trong công tác PCTT và $\mathrm{TKCN}$ của toàn ngành, cũng như đóng góp quan trọng và nỗ lực chung của tỉnh, địa phương và cả nước. Phương châm và nguyên tắc chỉ đạo của Bộ Công an là tổ chức thường trực nghiêm túc $24 / 24 \mathrm{~h}$ trong ngày, theo dõi sát diễn biến của thiên tai, bão, mưa lũ; ban hành nhiều Công điện để kịp thời chỉ đạo Công an các đơn vị, địa phương tổ chức triển khai công tác ứng phó với đợt thiên tai trên toàn quốc. Đảm bảo hệ thống thông tin liên lạc hoạt động thông suốt giữa cơ quan Bộ và Công an các đơn vị, địa phương. Tuy vậy, trong tình hình diễn biến thực tể của các trận, bão, lũ lụt và lũ quét, tại nhiều địa phương các chế độ về thông tin, báo cáo vẫn chưa thực sự nghiêm và đáp ứng được các yêu cầu của chế độ thông tin báo cáo.

Về kinh phí thực hiện các nhiệm vụ PCTT và TKCN, Bộ Công an luôn chủ động cấp phát kinh phí, vật tư và phương tiện cho Công an địa phương và các đơn vị, cũng như các nguồn kinh phí cấp phát bổ sung và hỗ trợ cho các hoạt động khắc phục và phục hồi các tổn thất và thiệt hại cho các khu vực bị ảnh hưởng. Kết quả đánh giá được tổng hợp trong Bảng 10.

Bảng 10. Đánh giá sơ bộ về nội dung liên quan đến nguồn lực, giai đoạn trong và sau thiên tai.

\begin{tabular}{|c|c|c|}
\hline Nhóm & Tiêu chí/nội dung & Đánh giá sơ bộ \\
\hline $\begin{array}{l}\text { Nguồn } \\
\text { lực }\end{array}$ & $\begin{array}{l}\text { - Đảm bảo hệ thống thông tin liên lạc } \\
\text { - Đảm bảo giảm thiểu các thiệt hại đến hoạt động sản xuất } \\
\text { (thu hoạch hoa màu, lúa, nuôi trồng thủy hải sản, ...). } \\
\text { - Đảm bảo nguồn lực tài chính phục vụ công tác hỗ trợ } \\
\text { ngay trong và sau thiên tai } \\
\text { - Đảm bảo thực hiện di dời kịp thời và hiệu quả các hộ gia } \\
\text { đình bị ảnh hường. } \\
\text { - Đảm bảo an toàn, vệ sinh môi trường và ANTT, an toàn } \\
\text { công trình công cộng và dân sinh trong điều kiện thiên tai } \\
\text { - Đảm bảo công tác cứu trợ và tiếp nhận cứu trợ }\end{array}$ & $\begin{array}{l}\text { Các hoạt động đã được thực hiện } \\
\text { theo phân công nhiệm vụ và trách } \\
\text { nhiệm của các CBCS, tuy nhiên } \\
\text { hạn chế về mặt cơ sở hạ tầng, trang } \\
\text { thiết bị và trình độ công nghệ, do } \\
\text { đó vẫn còn có những hạn chế nhất } \\
\text { định. }\end{array}$ \\
\hline
\end{tabular}

\subsubsection{Trình độ và kỹ năng}

Ngoài trình độ và kỹ năng trong thực hiện các hoạt động UPT, cũng cần đánh giá công tác đảm bảo an toàn cho lực lượng CBCS làm nhiệm vụ. Trên thực tế, có rất nhiều nguy hiểm cho lực lượng $\mathrm{CAND}$, đặc biệt trong công tác $\mathrm{TKCN}$. Mặc dù công tác chuẩn bị và huấn 
luyện lực lượng đã được thực hiện bài bản và liên tục được cập nhật và bổ sung, tuy nhiên trong điều kiện thiên tai, thời tiết và khó khăn về địa hình cũng như thiếu các trang thiết bị bảo hộ hiện đại, thiệt hại về người của lực lượng $\mathrm{CAND}$, đặc biệt trong công tác $\mathrm{TKCN}$, cứu hộ còn nhiều thử thách. Kết quả đánh giá được tổng kết trong Bảng 11.

Bảng 11. Đánh giá sơ bộ về nội dung liên quan đến nguồn lực, giai đoạn trong và sau thiên tai.

\begin{tabular}{|c|c|c|}
\hline Nhóm & Tiêu chí/nội dung & Đánh giá sơ bộ \\
\hline \multirow{2}{*}{$\begin{array}{ll}\text { Trình } & \text { độ } \\
\text { và } & \text { kỹ } \\
\text { năng }\end{array}$} & $\begin{array}{l}\text { - Úng dụng KHCN trong chỉ huy, điều hành và } \\
\text { phối hợp với các ngành/đơn vị có liên quan khác } \\
\text { trong thực hiện PCTT và TKCN }\end{array}$ & $\begin{array}{l}\text { Đã đang triển khai thực hiện các chương } \\
\text { trình, kế hoạch (Xây dựng và thành lập } 08 \\
\text { cụm tuyến liên kết vùng PCTT và TKCN } \\
\text { của } 08 \text { vùng trọng điểm thiên tai) }\end{array}$ \\
\hline & $\begin{array}{l}\text { - Đảm bảo an toàn cho lực lượng tham gia công tác } \\
\text { PCTT và TKCN }\end{array}$ & $\begin{array}{l}\text { Luôn được quan tâm và triển khai nhiều } \\
\text { giải pháp nhắm đảm bảo tính an toàn trong } \\
\text { ứng phó, khắc phục hậu quả thiên tai. }\end{array}$ \\
\hline
\end{tabular}

\subsection{Giai đoạn phục hồi và phát triển}

\subsubsection{Cơ cấu tổ chức}

Để có thể hướng tới tái thiết và phát triển lực lượng CAND, đặc biệt tham gia hiệu quả và an toàn công tác TKCN, Bộ Công an cần xây dựng và bổ sung các quy định cụ thể về đào tạo, cấp chứng chỉ huấn luyện kỹ năng nghiệp vụ chuyên sâu về công tác UPT. Xây dựng và thực hiện các chính sách khuyến khích hoạt động khoa học công nghệ, thu hút đầu tư, hợp tác quốc tế, huy động nguồn lực cho nghiên cứu ứng dụng, phục vụ công tác U’PT. Kết quả đánh giá được tổng kết trong Bảng 12.

Bảng 12. Đánh giá sơ bộ về nội dung cơ cấu tổ chức, giai đoạn phục hồi và phát triển.

\begin{tabular}{|c|c|c|}
\hline Nhóm & Tiêu chí/nội dung & Đánh giá sơ bộ \\
\hline $\begin{array}{l}\text { Cơ cấu } \\
\text { tổ chức }\end{array}$ & $\begin{array}{l}\text { - Đánh hiệu quả tổ chức thực hiện nhiệm vụ UPT; } \\
\text { - Xây dựng và bổ sung các chính sách đãi ngộ cán bộ } \\
\text { chiến sĩ thực hiện nhiệm vụ UPT. }\end{array}$ & $\begin{array}{l}\text { Đã được đặt ra trong Đề án thực hiện } \\
\text { giai đoạn 2016-2020 và tầm nhìn đến } \\
2030 \text {. }\end{array}$ \\
\hline
\end{tabular}

\subsubsection{Xây dựng và lập kế hoạch}

Việc lồng ghép các yêu cầu và quy định trong thực hiện UPT trong các kế hoạch, quy hoạch phát triển ngành, đã từng bước triển khai và thực hiện. Tuy nhiên chưa có nhiều báo cáo về kết quả thực hiện nhiệm vụ này. Bộ Công an cần xác định các mục tiêu cụ thể và tiêu chí đánh giá việc lồng ghép này trong các kế hoạch và đề án phát triển trung hạn và dài hạn của ngành. Kết quả đánh giá được tổng kết trong Bảng 13.

Bảng 13. Đánh giá sơ bộ về nội dung xây dựng và lập kế hoạch, giai đoạn phục hồi và phát triển.

\begin{tabular}{|c|c|c|}
\hline Nhóm & Tiêu chí/nội dung & Đánh giá sơ bộ \\
\hline $\begin{array}{l}\text { Xây dựng } \\
\text { và lập kế } \\
\text { hoạch }\end{array}$ & $\begin{array}{l}\text { - Lồng ghép các nội dung liên quan đến PCTT và } \\
\text { TKCN trong các kế hoạch, quy hoạch phát triển } \\
\text { ngành (gồm } 06 \text { nội dung quy định trong Khoản } 5 \\
\text { Điều } 15 \text { của Luật PCTT). }\end{array}$ & $\begin{array}{l}\text { Chưa thực hiện nhiều trong công tác xây } \\
\text { dựng và lập kế hoạch phát triển trung } \\
\text { hạn và dài hạn của ngành. }\end{array}$ \\
\hline
\end{tabular}

\subsubsection{Nguồn lực}

Để đảm bảo nguồn lực nhằm nâng cao hiệu quả và phát triển lực lượng CAND tham gia công tác UPBĐKH, PCTT và TKCN, Quyết định số 4147/QĐ-BCA-H43 ban hành ngày 
28/9/2016 [10]. đã xác định cụ thể các mục tiêu về nguồn nhân lực, nguồn lực về cơ sở hạ tầng, nguồn lực khoa học công nghệ và nguồn lực quốc tế. Trong đó: $100 \%$ cảnh sát PCCC tỉnh, thành phố có phòng cảnh sát cứu nạn cứu hộ; $100 \%$ phòng cảnh sát phòng cháy chữa cháy và cứu nạn, cứu hộ thuộc Công an tỉnh có đội cảnh sát cứu nạn, cứu hộ; $100 \%$ phòng cảnh sát PCCC quận, huyện có đội cảnh sát cứu nạn cứu hộ; $100 \%$ các đơn vị kiêm nhiệm, các đơn vị có chức năng tham gia công tác UPT thành lập lực lượng dự bị cơ động được trang bị phương tiện và huấn luyện kỹ năng; $100 \%$ các trường Công an, Công an các địa phương thành lập các đơn vị dự bị xung kích UPT là học sinh, sinh viên và đoàn viên thanh niên. Ngoài ra Bộ Công an cũng đặt ra một số các tiêu chí về phát triển khoa học công nghệ, các đề tài NCKH trong ngành hướng tới được áp dụng $100 \%$ trong triển khai và thực hiện công tác UPT. Kết quả đánh giá được tổng kết trong Bảng 14.

Bảng 14. Đánh giá sơ bộ về nội dung liên quan đến nguồn lực giai đoạn phục hồi và phát triển.

\begin{tabular}{|c|c|c|}
\hline Nhóm & Tiêu chí/nội dung & Đánh giá sơ bộ \\
\hline $\begin{array}{l}\text { Nguồn } \\
\text { lực }\end{array}$ & $\begin{array}{l}\text { - Đầu tư mới và nâng cấp các phương tiện, trang thiết bị, } \\
\text { nhu yếu phẩn, các công trình PCTT và nguồn lực khác; } \\
\text { - Nâng cấp và áp dụng khoa học công nghệ tiên tiến cho } \\
\text { các hệ thông thông tin liên lạc, hệ thống cảnh bảo và hệ } \\
\text { thống quản lý thông tin; } \\
\text { - Tăng cường hợp tác quốc tế, phát triển, trao đổi và chia } \\
\text { sẻ kinh nghiệm, KHCN và tài chính trong thực hiện } \\
\text { PCTT và TKCN. }\end{array}$ & $\begin{array}{l}\text { Đã được đề cập và từng bước thực } \\
\text { hiện trong các chiến lược và kế hoạch } \\
\text { phát triển của ngành, tuy nhiên thiếu } \\
\text { các số liệu cập nhận kết quả và tình } \\
\text { hình thực hiện. }\end{array}$ \\
\hline
\end{tabular}

\subsubsection{Trình độ và kỹ năng}

Trình độ và kỹ năng của cán bộ chiến sĩ trong ngành Công an, được đánh gia thông qua các đề án, dự án, chương trình về phát triển khoa học công nghệ và các buổi tập huấn nâng cao trình độ liên quan đến công tác UPT được tổ chức trong ngành. Kết quả đánh giá sơ bộ được tổng kết trong Bảng 15.

Bảng 15. Đánh giá sơ bộ về nội dung liên quan đến trình độ và kỹ năng giai đoạn phục hồi và phát triển.

\begin{tabular}{|c|c|c|}
\hline Nhóm & Tiêu chí/nội dung & Đánh giá sơ bộ \\
\hline $\begin{array}{ll}\text { Trình } & \text { độ } \\
\text { và } & \text { kỹ } \\
\text { năng } & \end{array}$ & $\begin{array}{l}\text { - Thực hiện các đề án, dự án, chương trình, kế hoạch } \\
\text { nâng cao trình độ chuyên môn của lực lượng CAND } \\
\text { trong PCTT và TKCN } \\
\text { - Tâp trung phát triển KHCN trong chỉ huy, điều hành và } \\
\text { phồi hợp với các ngành/đơn vị có liên quan khác trong } \\
\text { thực hiện PCTT và TKCN }\end{array}$ & $\begin{array}{l}\text { Đã được đề cập và từng bước thực } \\
\text { hiện trong các chiến lược và kế hoạch } \\
\text { phát triển của ngành, tuy nhiên thiếu } \\
\text { các số liệu cập nhận kết quả và tình } \\
\text { hình thực hiện. }\end{array}$ \\
\hline
\end{tabular}

\section{Kết luận}

Bài báo đã tiến hành phân tích các tiêu chí/nội dung đánh giá hiện trạng và đóng góp của ngành Công an trong công tác UPT ứng với 4 giai đoạn: (i) giai đoạn phòng ngừa và giảm thiểu, (ii) giai đoạn chuẩn bị, (iii) Giai đoạn trong và ngay sau thiên tai, (iv) giai đoạn phục hồi và tái thiết [17]. Các nội dung phân tích được thực hiện căn cứ vào kết quả điều tra khảo sát theo bảng hỏi, phỏng vấn sâu, và quan sát và trải nghiệm thực tế của tác giả bài báo tại địa bàn. Các kết quả phân tích tài liệu và điều tra khảo sát và đánh giá trên tất cả các lĩnh vực từ những địa bàn, vùng miền, lực lượng chuyên trách, kiêm nhiệm, dự bị, xung kích, cơ sở hạ tầng, cơ sở y tế, các cơ sở giam giữ, kho tàng, hành lang pháp lý số lượng $\mathrm{CBCS}$ tham gia UPT khi được huy động, cơ sở hạ tầng, trụ sở cần di dời, hệ thống thông tin liên lạc, cảnh báo, dự báo thiên tai, đề ra các phương án, kế hoạch thực hiện, các tình huống thiên tai cụ thể liên quan đến bão, lũ lụt và lũ quét. 
Kết quả phân tích và đánh giá các tiêu chí/nội dung đề xuất bước đầu cho thấy, ở cả cấp Bộ Công an và cấp tỉnh, trong cả 04 giai đoạn, phần lớn các nội dung về Cơ cấu tổ chức; Xây dựng, lập kế hoạch, Nguồn lực, Trình độ, kỹ năng của lực lượng CAND tham gia công tác PCTT và $\mathrm{TKCN}$ đều đã được lên kế hoạch và triển khai thực hiện. Kết quả đánh giá cho thấy, hiện nay giai đoạn phục hồi, tái thiết sau thiên tai phần nào còn bị hạn chế trong việc đầu tư nguồn lực thực hiện các nội dung cụ thể. Các giải pháp đang được áp dụng còn phần lớn tập trung công tác khắc phục hậu quả mang tính khẩn cấp, ngắn hạn. Khi đưa ra các giải pháp nhằm nâng cao hiệu quả và đóng góp của lực lượng CAND trong công tác U'PT, các giải pháp trong giai đoạn phục hồi và tái thiết cũng nhận được ít sự quan tâm của các $\mathrm{CBCS}$ so với 03 giai đoạn còn lại.

Trong thời gian tới, để tăng cường hiệu quả của ngành Công an trong công tác UPT, cần có giải pháp cụ thể nhằm: (1) Hoàn thiện tổ chức bộ máy hoạt động ứng phó với biến đổi khí hậu, PCTT và tìm kiếm cứu nạn; (2) Hoàn thiện cơ chế, chính sách về ứng phó với biến đổi khí hậu, PCTT và tìm kiếm cứu nạn; (3) Phát triển và đầu tư các nguồn lực về khoa học công nghệ (KHCN), hợp tác quốc tế (HTQT), liên kết vùng trong ứng phó với biến đổi khí hậu, PCTT và tìm kiếm cứu nạn; (4) Tuyên truyền, giáo dục, tập huấn, đào tạo nâng cao trình độ [10-12].

Đóng góp của tác giả: Xây dựng ý tưởng nghiên cứu: N.V.K., H.T.L.H., M.V.K.; Lựa chọn phương pháp nghiên cứu: N.V.K., H.T.L.H., M.V.K.; Xử lý số liệu: N.V.K., H.T.L.H.; Viết bản thảo bài báo: N.V.K., H.T.L.H., M.V.K., Đ.T.H., N.N.C.; Chỉnh sửa bài báo: N.V.K.

Lời cam đoan: Tập thể tác giả cam đoan bài báo này là công trình nghiên cứu của tập thể tác giả, chưa được công bố ở đâu, không được sao chép từ những nghiên cứu trước đây; không có sự tranh chấp lợi ích trong nhóm tác giả.

\section{Tài liệu tham khảo}

1. Coetzee, C.; Van Niekerk, D. Tracking the evolution of the disaster management cycle: A general system theory approach. Jàmbá: J. Disaster Risk Studies 2012, 4(1), $1-9$.

2. Sakalasooriya Nishan. Disaster Management Cycle, 2015.

3. Horita, F.E.A.; Degrossi, L.C.; de Assis, L.F.G.; Zipf, A.; de Albuquerque, J.P. (2013). The use of volunteered geographic information (VGI) and crowdsourcing in disaster management: a systematic literature review. VGI in Disaster Management: systematic literature review. Proceedings of the Nineteenth Americas Conference on Information Systems, Chicago, Illinois, August 15-17, 2013.

4. Holloway, A. Disaster risk reduction in southern Africa: hot rhetoric-cold reality. African Security Studies 2003, 12(1), 29-38.

5. Harrison, S.E.; Johnson, P.A. Crowdsourcing the disaster management cycle. Int. J. Inf. Syst. Crisis Response Manage. 2016, 8(4), 17-40.

6. Sawalha, I.H. A contemporary perspective on the disaster management cycle. Foresight, 2020.

7. Carter, W.N. Disaster management: A disaster manager's handbook, 2008.

8. Queensland Fire and Emergency Services. Queensland: Prevention, Prepareness and Recovery Disaster management guideline, 2018.

9. Ban Chỉ đạo Trung ương về phòng chống thiên tai. Sổ tay hướng dẫn xây dựng phương án ứng phó thiên tai theo các cấp độ rủi ro thiên tai, 2018.

10. Bộ Công An. Đề án Quy hoạch tổng thể lĩnh vực ứng phó với BĐKH, PCTT và TKCN ngành Công an đến năm 2020, tầm nhìn đến năm 2030, 2016.

11. Ban chỉ huy PCTT và TKCN tỉnh Nghệ An. Báo cáo tổng kết công tác PCTT và TKCN năm 2019, phương hướng nhiệm vụ PCTT và TKCN năm 2020.

12. Bộ Công An. Báo cáo thực hiện Chiến lược và Kế hoạch hành động quốc gia về biến 
đổi khí hậu. Kèm theo công văn số 3330/BCA-H06 ngày 4/11/2019. Bộ Công An. Hà Nội, Việt Nam, 2019.

13. Kế hoạch Ứng phó với biến đổi khí hậu, phòng chống thiên tai, tìm kiếm cứu nạn và phòng thủ dân sự của lực lượng Công an nhân dân năm 2021.

14. Ban Chỉ đạo UPT Bộ Công an. Báo cáo tổng kết công tác U'PVBĐKH, PCTT và TKCN năm 2020, phương hướng nhiệm vụ PCTT và TKCN năm 2021.

15. Hương, H.T.L. Nghiên cứu các giải pháp khoa học và công nghệ quản lý đa thiên tai, xây dựng công cụ hỗ trợ ra quyêt định ứng phó với đa thiên tai, áp dụng thí điểm cho khu vực ven biển Trung Trung Bộ. Báo cáo tổng kết đề tài, 2020.

16. Khiêm, N.V.; Hương, H.T.L.; Khiêm, M.V.; Chung, N.N. Tiêu chí đánh giá hiện trạng và đóng góp của ngành Công an trong phòng chống thiên tai và tìm kiếm cứu nạn. Tạp chí Khoa học Biến đổi khí hậu 2021, 18, 58-67.

17. Khiêm, N.V.; Hương, H.T.L.; Khiêm, M.V. Công tác bảo vệ môi trường, ứng phó với biến đổi khí hậu, phòng chống thiên tai trong lực lượng công an nhân dân. Tạp chí Khoa học Biến đổi khi hậu 2018, 7, 81-86.

\title{
The effectiveness and contribution of the police in response to climate change, disaster prevention and search and rescue
}

\section{Nguyen Van Khiem ${ }^{*}$, Huynh Thi Lan Huong', Mai Van Khiem ${ }^{3}$, Do Thi Huong 4 , Nguyen Ngoc Chung 5}

${ }^{1}$ Nguyen Van Khiem, Office of the Ministry of Public Security; khiemuptbca@gmail.com

${ }^{2}$ Huynh Thi Lan Huong, Institute of Meteorology, Hydrology and Climate Change; huynhlanhuong@gmail.com

${ }^{3}$ Mai Van Khiem, National Hydrometeorological Center; maikhiem1977@gmail.com

${ }^{4}$ Do Thi Huong, Institute of Meteorology, Hydrology and Climate Change; dohuong@gmail.com.

${ }^{5}$ Nguyen Ngoc Chung, Office of the Ministry of Public Security; chung.upt@gmail.com.

\begin{abstract}
Climate change is one of the biggest challenges of mankind in the 21st century, has been and will make comprehensive and profound changes to the process of global development and security. Climate change will increase the frequency and intensity of natural disasters. Over the years, the Government of Vietnam has made remarkable progress in disaster risk reduction and prevention. The Public Security sector is one of the ministries/sectors that make important contributions to Vietnam's efforts in disaster prevention, especially in response to climate change. To be able to effectively improve this contribution of the Public Security sector, it is necessary to assess the current status of the sector's climate change response, disaster prevention and search and rescue work. On the basis of applying a closed 4-step disaster risk management process: (1) Prevention, mitigation; (2) Get ready; (3) Responding during and immediately after natural disasters; (4) Restoration and reconstruction, this paper presents the results of the assessment in four groups of content: (i) Organizational structure; (ii) Development and planning, (iii) Resources, and (iv) Qualifications and skills of police forces involved in climate change response, disaster prevention and search and rescue .
\end{abstract}

Keywords: Responding to climate change; Disaster prevention; Search and Rescue. 